\title{
Evaluation of the Effect of Consciousness Energy Healing Treatment on Physicochemical and Thermal Properties of Flutamide
}

\author{
Trivedi $\mathrm{D}^{1}$, Trivedi $\mathrm{MK}^{1}$, Alice Branton ${ }^{1}$, Nayak $\mathrm{G}^{1}$ and Jana $\mathrm{S}^{2 *}$ \\ ${ }^{1}$ Trivedi Global, Inc. Henderson, USA \\ ${ }^{2}$ Trivedi Science Research Laboratory Pvt Ltd, India
}

*Corresponding author: Snehasis Jana, Trivedi Science Research Laboratory Pvt Ltd., Bhopal, India, Tel: +91-022-25811234; Email: publication@trivedieffect.com

\section{Research Article \\ Volume 2 Issue 3}

Received Date: September 19, 2018

Published Date: October 31, 2018

DOI: $10.23880 /$ oajpr-16000162

\section{Abstract}

Flutamide is used primarily to treat the prostate cancer, which blocks the action of exogenous testosterone by binding to the androgen receptor. The aim of this study was to evaluate the impact of the Trivedi Effect ${ }^{\circledR}{ }^{-C o n s c i o u s n e s s ~ E n e r g y ~}$ Healing Treatment on the physicochemical and thermal properties of flutamide using the modern analytical technique. The flutamide sample was divided into control and treated part. The control part did not receive any Energy Treatment, while the treated part received the Biofield Energy Treatment remotely by a renowned Biofield Energy Healer, Dahryn Trivedi. The PXRD peak intensities and crystallite sizes were significantly altered ranging from $-29.24 \%$ to $1.79 \%$ and $0.44 \%$ to $31.21 \%$ respectively; however, the average crystallite size was significantly increased by $19.13 \%$ in the treated sample compared with the control sample. The particle size values were altered by $0.12 \%\left(d_{10}\right) 2.9 \%\left(d_{50}\right), 7.52 \%\left(d_{90}\right)$, and $5.81 \%\{\mathrm{D}(4,3)\}$, thus, the specific surface area was decreased by $0.55 \%$ in the treated sample compared to the control sample. The melting point and latent heat of fusion of the treated sample were increased by $0.63 \%$ and $5.31 \%$, respectively compared to the control sample. The total weight loss was decreased by $1.19 \%$; however, the residue amount was increased by $1.18 \%$ in the treated flutamide compared with the control sample. The Biofield Energy Treatment might have generated a new polymorphic form of flutamide which would be more efficacious in the pharmaceutical formulations for the treatment of prostate cancer.

Keywords: Flutamide; Consciousness Energy Healing Treatment; The Trivedi Effect ${ }^{\circledR}$; Complementary and Alternative Medicine; PXRD; Particle size; DSC; TGA/DTG

Abbreviations: NSAA: Nonsteroidal Antiandrogen; NIH/NCCAM: National Institutes of Health/National Center for Complementary and Alternative Medicine;
CAM: Complementary and Alternative Medicine; PXRD: Powder X-Ray Diffraction, PSA: Particle Size Analysis; DSC: Differential Scanning Calorimetry; TGA: Thermogravimetric Analysis; DTG: Differential Thermo 


\section{Open Access Journal of Pharmaceutical Research}

Gravimetric Analysis.

\section{Introduction}

Flutamide is an acetanilide, nonsteroidal antiandrogen (NSAA) having the chemical name, 2-methyl-N-[4-nitro-3 (trifluoromethyl) phenyl] propanamide [1-3]. Capsules of eulexin contain flutamide, orally active anti-androgen, which is used primarily to treat men with prostate cancer [4]. This can be used as independent drug or is used with other medications as well as with radiation treatments [5]. Testosterone, a natural hormone, helps the prostate cancer to grow and spread. The role of flutamide is to block the effects of testosterone, thus slowing down the growth and spread of prostate cancer [6]. Irregular consumption of this medicine or stopping medications before it completely gets cured, could allow the cancer to spread more rapidly. Overdose may cause hypoactivity, piloerection, slow respiration, ataxia, and/or lacrimation, anorexia, tranquilization, emesis, and methemoglobinemia [7]. However, the flutamide overdose ordinarily associated with symptoms or considered to be life-threatening has not been established.

Study of the physicochemical properties of a pharmaceutical product regarding its dissolution and absorption is crucial for the formulation. It was observed that the Biofield Energy Healing Treatment (the Trivedi Effect ${ }^{\circledR}$ ) has the considerable impact on various properties such as particle size, surface area, and other chemical and thermal behaviour of pharmaceutical/nutraceutical [8-11]. The Trivedi Effect ${ }^{\circledR}$ is a natural and scientifically proven phenomenon in which a person can harness this inherently intelligent energy and transmit it anywhere on the planet through the possible mediation of neutrinos [8]. Every living organism possesses this kind of unique energy surrounding the body known as the "Biofield Energy", which is infinite, para-dimensional electromagnetic field. Biofield (Putative Energy Fields) based Energy Healing Therapies have been reported with significant outcomes against various disease conditions [12]. The National Institutes of Health/National Center for Complementary and Alternative Medicine (NIH/NCCAM) recommend and included the Energy therapy under the Complementary and Alternative Medicine (CAM) category along with other therapies, which include homeopathy, Ayurvedic medicine, naturopathy, Tai Chi, Qi Gong, acupuncture, acupressure, Reiki, healing touch, hypnotherapy, Rolfing, etc. The CAM has been accepted by the most of the U.S. population with several advantages $[13,14]$. The Trivedi
Effect ${ }^{\circledR}$-Consciousness Energy Healing Treatment has been widely reported with astounding capability to alter the characteristic properties of the several non-living materials and living object(s), i.e. metals and ceramic, organic compounds, nutraceutical/pharmaceuticals, and crops [9-11,15-23]. The Consciousness Energy Healing Treatment has also enhanced the bioavailability of pharmaceutical/nutraceutical compounds [24-26]. This study was designed to determine the impact of the Trivedi Effect ${ }^{\circledR}$-Consciousness Energy Healing Treatment on the physicochemical and thermal properties of flutamide using powder X-ray diffraction (PXRD), particle size analysis (PSA), differential scanning calorimetry (DSC), and thermogravimetric analysis (TGA)/Differential thermo gravimetric analysis (DTG).

\section{Materials and Methods}

\section{Chemicals and Reagents}

The flutamide was purchased from Tokyo Chemical Industry Co. Ltd. All other chemicals used during the experiments were of analytical grade available in India.

\section{Consciousness Energy Healing Treatment Strategies}

The flutamide was the test sample divided into two parts. One part of flutamide was considered as control sample (no Biofield Energy Treatment was provided). Consequently, the second part of flutamide was treated with the Trivedi Effect ${ }^{\circledR}$-Energy of Consciousness Healing Treatment remotely under standard laboratory conditions for 3 minutes and was called the Biofield Energy Treated flutamide sample. This Biofield Energy Treatment was provided through the healer's unique energy transmission process by the renowned Biofield Energy Healer, Dahryn Trivedi, USA, to the second part of the test sample. Further, the control sample was treated with a "sham" healer. The "sham" healer did not have any knowledge about the Biofield Energy Treatment. After the treatment, the Biofield Energy Treated and untreated sample were both kept in sealed conditions and characterized using PXRD, PSA, DSC, and TGA techniques.

\section{Characterization}

Powder X-ray Diffraction (PXRD) Analysis: The PXRD analysis of flutamide was performed with the help of Rigaku MiniFlex-II Desktop X-ray diffractometer (Japan) $[27,28]$. The average size of individual crystallites was calculated from XRD data using the Scherrer's formula (1) 


\section{Open Access Journal of Pharmaceutical Research}

$$
\mathrm{G}=\mathrm{k} \lambda / \beta \cos \theta(1)
$$

Where $\mathrm{k}$ is the equipment constant (0.94), $\mathrm{G}$ is the crystallite size in $\mathrm{nm}, \lambda$ is the radiation wavelength

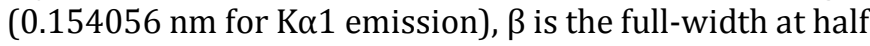
maximum (FWHM), and $\theta$ is the Bragg angle [29]. The \% change in crystallite size $(\mathrm{G})$ of flutamide was calculated using the following equation 2 :

$$
\% \text { change in crystallite size }=\frac{\left[\mathrm{G}_{\text {Treated }}-\mathrm{G}_{\text {Control }}\right]}{\mathrm{G}_{\text {Contrl }}} \times 100(2)
$$

Where $\mathrm{G}_{\text {Control }}$ and $\mathrm{G}_{\text {Treated }}$ are the crystallite size of the control and the Biofield Energy Treated samples, respectively.

Particle Size Analysis (PSA): The particle size analysis of flutamide was conducted on Malvern Mastersizer 2000, from the UK with a detection range between $0.01 \mu \mathrm{m}$ to $3000 \mu \mathrm{m}$ using wet method [30,31]. The sample unit (Hydro MV) was filled with a dispersant medium (sunflower oil) and operated the stirrer at $2500 \mathrm{rpm}$. The PSA analysis of flutamide was performed to obtain the average particle size distribution. Where, $d(0.1) \mu \mathrm{m}$, $\mathrm{d}(0.5) \mu \mathrm{m}, \mathrm{d}(0.9) \mu \mathrm{m}$ represent particle diameter corresponding to $10 \%, 50 \%$, and $90 \%$ of the cumulative distribution. $\mathrm{D}(4,3)$ represents the average mass-volume diameter, and SSA is the specific surface area $\left(\mathrm{m}^{2} / \mathrm{g}\right)$. The calculations were done by using software Mastersizer Ver. 5.54 .

The percent change in particle size (d) for at below $10 \%$ level $\left(d_{10}\right), 50 \%$ level $\left(d_{50}\right), 90 \%$ level $\left(d_{90}\right)$, and $D(4,3)$ was calculated using following equation 3 :

$$
\% \text { change in particle size }=\frac{\left[\mathrm{d}_{\text {Treated }}-\mathrm{d}_{\text {Control }}\right]}{\mathrm{d}_{\text {Control }}} \times 100(3)
$$

Where, $d_{\text {Control }}$ andd $d_{\text {Treated }}$ are the particle size $(\mu \mathrm{m})$ at below $10 \%$ level $\left(\mathrm{d}_{10}\right), 50 \%$ level $\left(\mathrm{d}_{50}\right)$, and $90 \%$ level $\left(d_{90}\right)$ of the control and the Biofield Energy Treated samples, respectively. Percent change in surface area (S) was calculated using following equation 4 :

$$
\% \text { change in surface area }=\frac{\left[\mathrm{S}_{\text {Treated }}-\mathrm{S}_{\text {Control }}\right]}{\mathrm{S}_{\text {Control }}} \times 100(4)
$$

Where $S_{\text {Control }}$ and $S_{\text {Treated }}$ are the surface area of the control and the Biofield Energy Treated flutamide, respectively.

Differential Scanning Calorimetry (DSC): The DSC analysis of flutamide was performed with the help of DSC Q200, TA instruments. A sample of $\sim 1-5 \mathrm{mg}$ was loaded to the aluminium sample pan at a heating rate of $10^{\circ} \mathrm{C} / \mathrm{min}$ from $30^{\circ} \mathrm{C}$ to $350^{\circ} \mathrm{C}[30,31]$. The $\%$ change in melting point (T) was calculated using the following equation 5 :
$\%$ change in melting point $=\frac{\left[\mathrm{T}_{\text {Treated }}-\mathrm{T}_{\text {Control }}\right]}{\mathrm{T}_{\text {Control }}} \times 100(5)$ Where $\mathrm{T}_{\text {control }}$ and $\mathrm{T}_{\text {Treated }}$ is the melting point of the control and treated samples, respectively.

The Percent change in the latent heat of fusion $(\Delta \mathrm{H})$ was calculated using the following equation 6 :

$$
\% \text { change in latent heat of fusion }=\frac{\left[\Delta \mathrm{H}_{\text {Treated }}-\Delta \mathrm{H}_{\text {Control }}\right]}{\Delta \mathrm{H}_{\text {Control }}} \times 100
$$

Where $\Delta \mathrm{H}_{\text {Control }}$ and $\Delta \mathrm{H}_{\text {Treated }}$ are the latent heat of fusion of the control and treated flutamide, respectively.

\section{Thermal Gravimetric Analysis (TGA)/ Differential thermogravimetric analysis (DTG):}

TGA/DTG thermograms of flutamide were obtained with the help of TGA Q50 TA instruments. A sample of $5 \mathrm{mg}$ was loaded to the platinum crucible at a heating rate of $10^{\circ} \mathrm{C} / \mathrm{min}$ from $25^{\circ} \mathrm{C}$ to $1000^{\circ} \mathrm{C}$ with the recent literature $[30,31]$. The $\%$ change in weight loss $(\mathrm{W})$ was calculated using the following equation 7 :

$$
\% \text { change in weight loss }=\frac{\left[\mathrm{w}_{\text {Treated }}-\mathrm{W}_{\text {Control }}\right]}{\mathrm{w}_{\text {Control }}} \times 100(7)
$$

Where $\mathrm{W}_{\text {Control }}$ and $\mathrm{W}_{\text {Treated }}$ are the weight loss of the control and the Biofield Energy Treated flutamide, respectively.

The $\%$ change in maximum thermal degradation temperature $\left(\mathrm{T}_{\max }\right)(\mathrm{M})$ was calculated using the following equation 8:

$$
\% \text { change in } \operatorname{Tmax}(\mathrm{M})=\frac{\left[\mathrm{M}_{\text {Treated }}-\mathrm{M}_{\text {Control }}\right]}{\mathrm{M}_{\text {Control }}} \times 100 \text { (8) }
$$

Where $\mathrm{M}_{\text {Control }}$ and $\mathrm{M}_{\text {Treated }}$ are the $\mathrm{T}_{\max }$ values of the control and the Biofield Energy Treated flutamide, respectively.

\section{Results and Discussion}

\section{Powder X-ray Diffraction (PXRD) Analysis}

The control and the Biofield Energy Treated flutamide showed sharp and intense peaks (Figure 1) in the PXRD diffract grams indicated that both the samples were crystalline in nature. The PXRD diffractograms of the control and the Biofield Energy Treated samples showed highest peak intensity at $2 \theta$ near to $8.6^{\circ}$ (Table 1 , entry 1 ). The peak intensities of the Biofield Energy Treated flutamide were significantly altered ranging from $29.24 \%$ to $1.79 \%$ compared to the control sample (Table 1). 

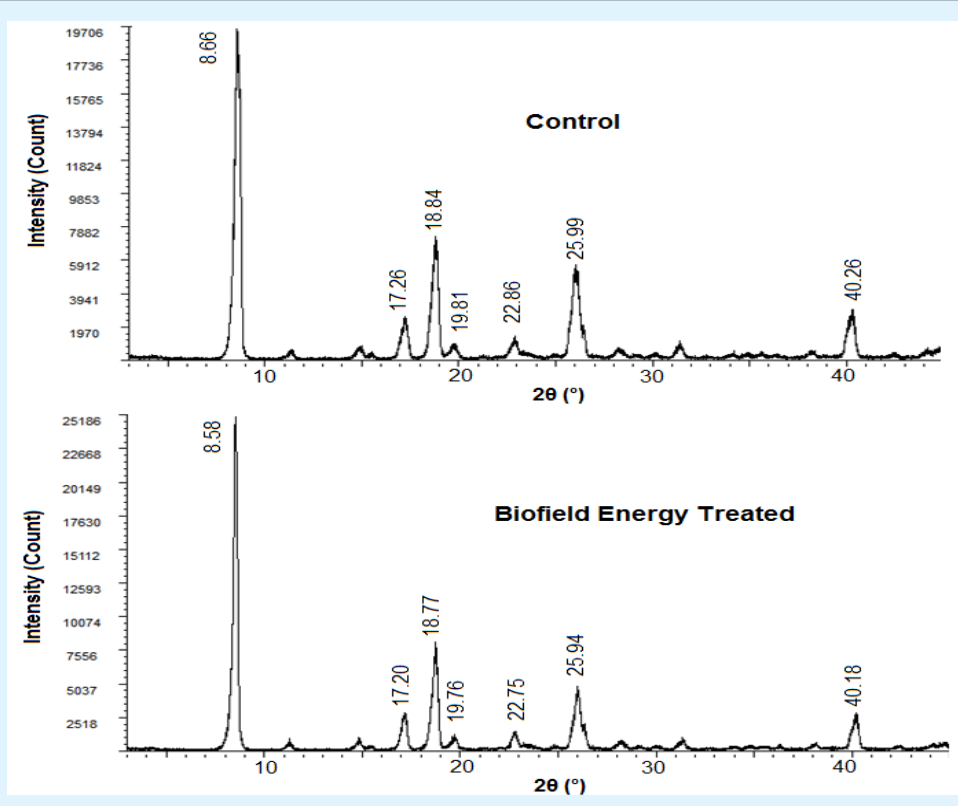

Figure 1: PXRD Diffractograms of the control and the Biofield Energy Treated flutamide.

\begin{tabular}{|c|c|c|c|c|c|c|c|c|}
\hline \multirow{2}{*}{ Entry No. } & \multicolumn{3}{|c|}{ Bragg angle $\left({ }^{\circ} \mathbf{2} \boldsymbol{\theta}\right)$} & \multicolumn{3}{|c|}{ Intensity (cps) } & \multicolumn{3}{c|}{ Crystallite size (G, nm) } \\
\cline { 2 - 9 } & Control & Treated & Control & Treated & \% change a & Control & Treated & \% changeb $^{\mathbf{b}}$ \\
\hline 1 & 8.66 & 8.58 & 5005 & 4917 & -1.76 & 226.7 & 296 & 30.57 \\
\hline 2 & 17.26 & 17.2 & 670 & 682 & 1.79 & 208 & 240 & 15.38 \\
\hline 3 & 18.84 & 18.77 & 1926 & 1934 & 0.42 & 206.8 & 232.1 & 12.23 \\
\hline 4 & 19.81 & 19.76 & 243 & 229 & -5.76 & 173 & 227 & 31.21 \\
\hline 5 & 22.86 & 22.75 & 435 & 393 & -9.66 & 189 & 243 & 28.57 \\
\hline 4 & 25.99 & 25.94 & 1956 & 1384 & -29.24 & 159.8 & 160.5 & 0.44 \\
\hline 5 & 40.26 & 40.18 & 853 & 665 & -22.04 & 213 & 241 & 13.15 \\
\hline
\end{tabular}

Table 1: PXRD Data for the Control and the Biofield Energy Treated Flutamide.

adenotes the percentage change in the relative intensity of the Biofield Energy Treated sample with respect to the control sample; bdenotes the percentage change in the crystallite size of the Biofield Energy Treated sample with respect to the control sample.

The crystallite sizes of the Biofield Energy Treated flutamide was significantly increased ranging from $0.44 \%$ to $31.21 \%$ with respect to the control sample. Overall, the average crystallite size of the Biofield Energy Treated flutamide $(234.23 \mathrm{~nm})$ was significantly increased by $19.13 \%$ compared with the control sample $(196.61 \mathrm{~nm})$.

The alterations in peak intensities and the crystallite sizes indicate the altered morphology of the Biofield Energy Treated flutamide crystal compared to the control sample. The peak intensity of each diffraction face on the crystalline compound changes according to the crystal morphology, and alterations in the PXRD pattern provide the proof of polymorphic transitions [32-34]. Different polymorphic forms of pharmaceuticals have a significant effect on the drug performance, such as bioavailability, therapeutic efficacy, and toxicity. Also, because of their different thermodynamic and physicochemical properties like melting point, energy, stability, and especially solubility, they differ from the control one $[35,36]$. Thus, it can be anticipated that the Trivedi Effect ${ }^{\circledR}$ Treated flutamide would be better in designing pharmaceutical formulations containing flutamide. 


\section{Open Access Journal of Pharmaceutical Research}

\section{Particle Size Analysis (PSA)}

The particle size distribution analysis of both the control and the Biofield Energy Treated flutamide were performed and the comparisons of distribution are presented in Table 2. The particle size values of the control flutamide at $\mathrm{d}_{10}, \mathrm{~d}_{50}, \mathrm{~d}_{90}$, and $\mathrm{D}(4,3)$ were 52.442 $\mu \mathrm{m}, 209.768 \mu \mathrm{m}, 677.399 \mu \mathrm{m}$, and $295.780 \mu \mathrm{m}$, respectively. Similarly, the particle sizes of the Biofield Energy Treated flutamide at $\mathrm{d}_{10}, \mathrm{~d}_{50}, \mathrm{~d}_{90}$, and $\mathrm{D}(4,3)$ were $52.364 \mu \mathrm{m}, 215.864 \mu \mathrm{m}, 728.364 \mu \mathrm{m}$, and $312.969 \mu \mathrm{m}$ respectively. Therefore, the particle size values in Dahryn
Trivedi's Biofield Energy Treated flutamide were decreased at $\mathrm{d}_{10}$ by $0.12 \%$ and increased at $\mathrm{d}_{50}, \mathrm{~d}_{90}$, and $\mathrm{D}$ $(4,3)$ by $2.90 \%, 7.52 \%$, and $5.81 \%$, respectively compared to the control sample. The specific surface area of the Biofield Energy Treated flutamide $\left(0.0899 \mathrm{~m}^{2} / \mathrm{g}\right)$ was decreased negligibly by $0.55 \%$ compared with the control sample $\left(0.0904 \mathrm{~m}^{2} / \mathrm{g}\right)$. Hence, it can be assumed that the Trivedi Effect ${ }^{\circledR}$-Consciousness Energy Healing Treatment might act like an external force for reducing the particle size of flutamide [37]. Thus, the Trivedi Effect ${ }^{\circledR}$ Treated flutamide might offer better bioavailability compared with the untreated sample.

\begin{tabular}{|c|c|c|c|c|c|}
\hline Parameter & $\mathbf{d}_{\mathbf{1 0}}(\boldsymbol{\mu m})$ & $\mathbf{d}_{\mathbf{5 0}}(\boldsymbol{\mu m})$ & $\mathbf{d}_{\mathbf{9 0}}(\boldsymbol{\mu m})$ & $\mathbf{D} \mathbf{( 4 , 3 ) ( \boldsymbol { \mu m } )}$ & $\mathbf{S S A}\left(\mathbf{m}^{\mathbf{2}} / \mathbf{g}\right)$ \\
\hline Control & 52.442 & 209.768 & 677.399 & 295.78 & 0.0904 \\
\hline Biofield Energy Treated $^{*} 52.364$ & 215.864 & 728.364 & 312.969 & 0.0899 \\
\hline Percent change $^{*}(\%)$ & -0.12 & 2.9 & 7.52 & 5.81 & -0.55 \\
\hline
\end{tabular}

Table 2: Particle Size Distribution of the Control and the Biofield Energy Treated Flutamide.

$\mathrm{d}_{10}, \mathrm{~d}_{50}$, and $\mathrm{d}_{90}$ : particle diameter corresponding to $10 \%, 50 \%$, and $90 \%$ of the cumulative distribution, $\mathrm{D}(4,3)$ : the average mass-volume diameter, and SSA: the specific surface area. ${ }^{*}$ denotes the percentage change in the Particle size distribution of the Biofield Energy Treated sample with respect to the control sample.

\section{Differential Scanning Calorimetry (DSC) Analysis}

DSC analysis has been performed to characterize the thermal behavior of both control and the Biofield Energy Treated flutamide (Table 3 \& Figure 2). The DSC thermograms of the control and the Biofield Energy Treated flutamide showed a sharp endothermic peak at 112.62 and $113.33^{\circ} \mathrm{C}$, respectively (Figure 2). The melting point of the Biofield Energy Treated flutamide was slightly increased by $0.63 \%$ compared with the control sample (Table 3).

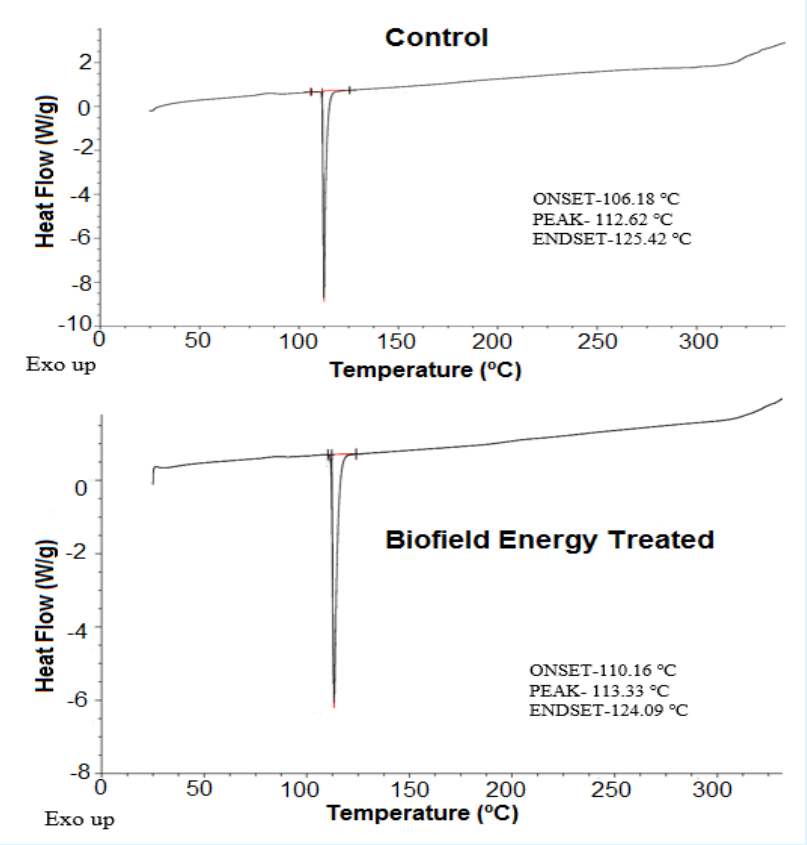

Figure 2: DSC Thermograms of the Control and the Biofield Energy Treated Flutamide 


\begin{tabular}{|c|c|c|}
\hline Sample & Melting point $\left({ }^{\circ} \mathbf{C}\right)$ & $\mathbf{\Delta H}(\mathbf{J} / \mathbf{g})$ \\
\hline Control Sample & 112.62 & 96 \\
\hline Biofield Energy Treated & 113.33 & 101.1 \\
\hline \% Change* & 0.63 & 5.31 \\
\hline
\end{tabular}

Table 3: DSC Data for Both Control and the Biofield Energy Treated Samples of Flutamide.

$\Delta \mathrm{H}$ : Latent heat of fusion, ${ }^{*}$ denotes the percentage change of the Biofield Energy Treated sample with respect to the control sample.

The latent heat of fusion $\left(\Delta \mathrm{H}_{\text {fusion }}\right)$ of the Biofield Energy Treated flutamide $(101.1 \mathrm{~J} / \mathrm{g})$ was significantly increased by $5.31 \%$ compared with the control sample $(96.0 \mathrm{~J} / \mathrm{g})$ (Table 3). The change in the latent heat of fusion can be attributed to the disrupted molecule chains and the crystal structure [37]. Thus, it can be assumed that Dahryn Trivedi's Biofield Energy Treatment might be responsible for the disruption the molecular chains and crystal structure of flutamide which was the cause of increased melting point of the treated sample compared with the control sample.

\section{Thermal Gravimetric Analysis (TGA)/ Differential thermogravimetric analysis (DTG)}

The TGA thermograms of the control and the Biofield Energy Treated samples displayed one step of thermal degradation (Figure 3). The total weight loss in the Biofield Energy Treated flutamide was decreased by $1.4 \%$ compared with the control sample (Table 4). Therefore, the residue amount was increased by $1.18 \%$ in the Biofield Energy Treated flutamide compared to the control sample (Table 4).

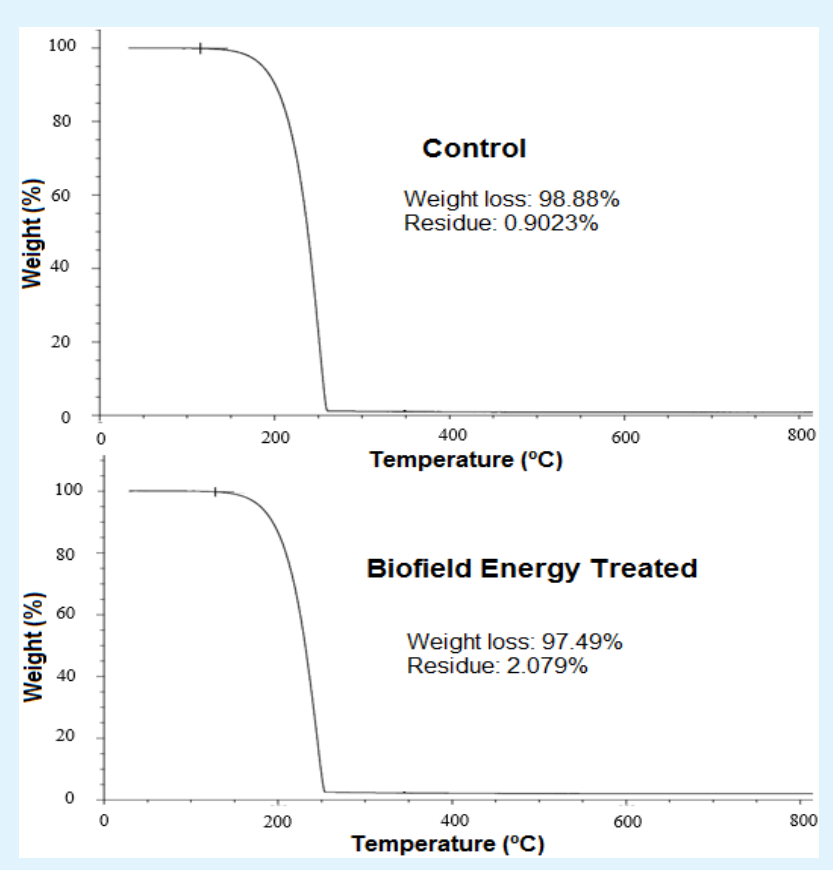

Figure 3: TGA Thermograms of the Control and the Biofield Energy Treated Flutamide

\begin{tabular}{|c|c|c|c|}
\hline \multirow{2}{*}{ Sample } & \multicolumn{2}{|c|}{ TGA } & DTG \\
\cline { 2 - 4 } & Total weight loss $(\mathbf{\%})$ & Residue \% & $\mathbf{T}_{\max }\left({ }^{\circ} \mathbf{C}\right)$ \\
\hline Control & 99.1 & 0.902 & 250.7 \\
\hline Biofield Energy Treated & 97.92 & 2.079 & 244.22 \\
\hline \% Change & -1.19 & 1.18 & -2.58 \\
\hline
\end{tabular}

Table 4: TGA/DTG data of the control and the Biofield Energy Treated samples of flutamide

*denotes the percentage change of the Biofield Energy Treated sample with respect to the control sample, $\mathrm{T}_{\max }=$ the temperature at which maximum weight loss takes place in TG or peak temperature in DTG. 


\section{Open Access Journal of Pharmaceutical Research}

The DTG thermograms of the control and the Biofield Energy Treated flutamide shown only one peak (Figure 4). The control flutamide was thermally stable up to $135.63^{\circ} \mathrm{C}$, while the Biofield Energy Treated flutamide was stable up to $109.09^{\circ} \mathrm{C}$. The $\mathrm{T}_{\max }$ of the Biofield Energy
Treated sample was significantly decreased by $2.58 \%$ compared with the control sample (Table 4). Overall, TGA/DTG revealed that the thermal stability of the Biofield Energy Treated flutamide was significantly decreased compared with the control sample.

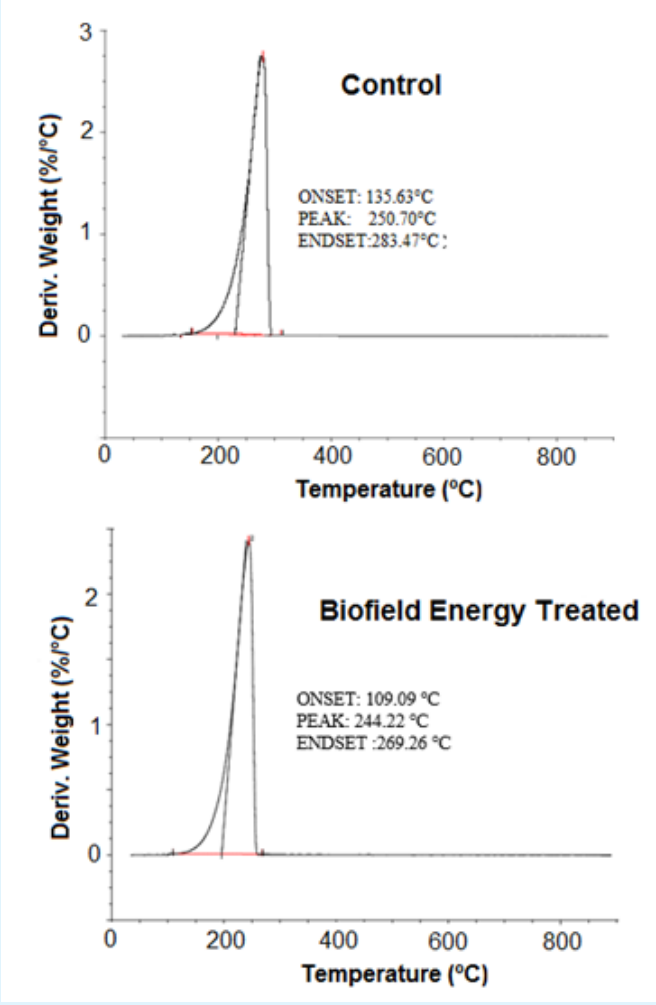

Figure 4: DTG Thermograms of the Control and the Biofield Energy Treated flutamide.

\section{Conclusions}

The Trivedi Effect ${ }^{\circledR}$-Consciousness Energy Healing Treatment showed a significant effects on the relative intensities, morphology, particle size distribution, and thermal properties of flutamide. The PXRD results indicated that the relative peak intensities of the Dahryn Trivedi's Biofield Energy Treated flutamide were altered ranging from $-29.24 \%$ to $1.79 \%$ compared with the control sample. Similarly, the crystallite sizes of the Biofield Energy Treated sample were significantly increased up to $31.21 \%$ compared to the control sample. The particle size values of the Biofield Energy Treated flutamide were decreased negligibly by $0.12 \%$ at $\mathrm{d}_{10}$ and increased at $\mathrm{d}_{50}, \mathrm{~d}_{90}$, and $\mathrm{D}(4,3)$ by $2.9 \%, 7.52 \%$, and $5.81 \%$, respectively compared to the control sample. The specific surface area of the Biofield Energy Treated flutamide was decreased by $0.55 \%$ compared to the control sample. The DSC data revealed that the melting point and $\Delta \mathrm{H}_{\text {fusion }}$ of the Biofield Energy Treated flutamide were increased by $0.63 \%$ and $5.31 \%$, respectively compared with the control sample. The total weight loss was decreased by $1.19 \%$ in TGA; therefore, the residue amount was increased by $1.18 \%$ in the Biofield Energy Treated flutamide compared with the control sample. The $\mathrm{T}_{\max }$ of the Biofield Energy Treated sample was significantly decreased by $2.58 \%$ compared with the control sample. Thus, the Trivedi Effect ${ }^{\circledR}$-Consciousness Energy Healing Treatment might lead to the generation of a new polymorphic form of flutamide which would be more thermally stable, become more bioavailable compared to the untreated sample. The Biofield Energy 


\section{Open Access Journal of Pharmaceutical Research}

Treated flutamide would more efficacious in nutraceutical and pharmaceutical formulations for the better therapeutic response against prostate cancer.

\section{References}

1. Elks J (1990) The Dictionary of Drugs: Chemical Data: Chemical Data, Structures and Bibliographies, pp: 2062.

2. Nominum I (2000) International Drug Directory. Thruven Health Analytics, pp: 1-2.

3. Budavari S (2003) The Merck index. Whitehouse Station: Merck and Co Inc.

4. Goldspiel BR, Kohler DR (1990) Flutamide: An antiandrogen for advanced prostate cancer. DICP 24(6): 616-623.

5. Salgado HRN, Menezes M, Storti MPB (2005) Determination of flutamide in tablets by highperformance liquid chromatography. Acta Farm Bonaerense 24(2): 246-249.

6. Sufrin G, Coffey DS (1976) Flutamide. Mechanism of action of a new nonsteroidal antiandrogen. Invest Urol 13(6): 429-434.

7. Mizuno K, Hayashi Y, Kojima Y, Kurokawa S, Sasaki S, et al. (2006) Influence for testicular development and histological peculiarity in the testes of flutamideinduced cryptorchid rat model. Int J Urol 14(1): 67-72.

8. Trivedi MK, Mohan TRR (2016) Biofield energy signals, energy transmission and neutrinos. American Journal of Modern Physics 5(6): 172-176.

9. Trivedi MK, Branton A, Trivedi D, Nayak G, Lee AC, et al. (2016) Impact of biofield energy treated herbomineral formulation (The Trivedi Effect $^{\circledR}$ ) on mouse dendritic and splenocyte cells for modulation of pro-inflammatory cytokines. International Journal of Immunology 4: 35-45.

10. Trivedi MK, Branton A, Trivedi D, Nayak G, Wellborn BD, et al. (2017) Effect of the energy of consciousness (The Trivedi Effect ${ }^{\circledR}$ ) on the structural properties and isotopic abundance ratio of magnesium gluconate using LC-MS and NMR spectroscopy. Advances in Biochemistry 5: 7-15.

11. Trivedi MK, Branton A, Trivedi D, Nayak G, Afaganis AE, et al. (2017) An Impact of energy of consciousness (The Trivedi Effect ${ }^{\circledR}$ ) on the physicochemical, thermal, structural, and behavioral properties of magnesium gluconate. Biomedical Sciences 3(2): 42-54.
12. Rubik B, Muehsam D, Hammerschlag R, Jain S (2015) Biofield science and healing: history, terminology, and concepts. Glob Adv Health Med 4(Suppl): 8-14.

13. Barnes PM, Bloom B, Nahin RL (2008) Complementary and alternative medicine use among adults and children: United States, 2007. Natl Health Stat Report 10(12): 1-23.

14. Koithan M (2009) Introducing complementary and alternative therapies. J Nurse Pract 5(1): 18-20.

15. Trivedi MK, Tallapragada RM, Branton A, Trivedi D, Nayak G, et al. (2015) Characterization of physical and structural properties of aluminum carbide powder: Impact of biofield treatment. J Aeronaut Aerospace Eng 4(1): 142.

16. Trivedi MK, Patil S, Tallapragada RM (2013) Effect of biofield treatment on the physical and thermal characteristics of vanadium pentoxide powders. J Material Sci Eng S11: 001.

17. Trivedi MK, Branton A, Trivedi D, Nayak G, Sethi KK, et al. (2016) Gas chromatography-mass spectrometry based isotopic abundance ratio analysis of biofield energy treated methyl-2-napthylether (Nerolin). American Journal of Physical Chemistry 5: 80-86.

18. Trivedi MK, Branton A, Trivedi D, Nayak G, Bairwa K, et al. (2015) Spectroscopic characterization of disodium hydrogen orthophosphate and sodium nitrate after biofield treatment. J Chromatogr Sep Tech 6: 282.

19. Trivedi MK, Branton A, Trivedi D, Nayak G, Panda P, et al. (2016) Evaluation of the isotopic abundance ratio in biofield energy treated resorcinol using gas chromatography-mass spectrometry technique. Pharm Anal Acta 7: 481.

20. Trivedi MK, Tallapragada RM, Branton A, Trivedi D, Nayak G, et al. (2015) Potential impact of biofield treatment on atomic and physical characteristics of magnesium. Vitam Miner 3: 129.

21. Trivedi MK, Patil S, Shettigar H, Bairwa K, Jana S (2015) Effect of biofield treatment on spectral properties of paracetamol and piroxicam. Chem Sci J 6: 98.

22. Trivedi MK, Branton A, Trivedi D, Nayak G, Gangwar M, et al. (2015) Agronomic characteristics, growth analysis, and yield response of biofield treated mustard, cowpea, horse gram, and groundnuts. International Journal of Genetics and Genomics 3: 7480 . 


\section{Open Access Journal of Pharmaceutical Research}

23. Trivedi MK, Branton A, Trivedi D, Nayak G, Mondal SC, et al. (2015) Evaluation of plant growth, yield and yield attributes of biofield energy treated mustard (Brassica juncea) and chick pea (Cicer arietinum) seeds. Agriculture, Forestry and Fisheries 4(6): 291295.

24. Branton A, Jana S (2017) Effect of The biofield energy healing treatment on the pharmacokinetics of 25hydroxyvitamin D3 $\left[25(\mathrm{OH}) \mathrm{D}_{3}\right]$ in rats after a single oral dose of vitamin $\mathrm{D}_{3}$. American Journal of Pharmacology and Phytotherapy 2(1): 11-18.

25. Branton A, Jana S (2017) The influence of energy of consciousness healing treatment on low bioavailable resveratrol in male Sprague Dawley rats. International Journal of Clinical and Developmental Anatomy 3(3): 9-15.

26. Branton A, Jana S (2017) The use of novel and unique biofield energy healing treatment for the improvement of poorly bioavailable compound, berberine in male Sprague Dawley rats. American Journal of Clinical and Experimental Medicine 5(4): 138-144.

27. (1997) Desktop X-ray Diffractometer "MiniFlex+". The Rigaku Journal 14: 29-36.

28. Zhang T, Paluch K, Scalabrino G, Frankish N, Healy AM, et al. (2015) Molecular structure studies of (1S,2S)-2benzyl-2,3-dihydro-2-(1Hinden-2-yl)-1H-inden-1-ol. J Mol Struct 5(1083): 286-299.

29. Langford JI, Wilson AJC (1978) Scherrer after sixty years: A survey and some new results in the determination of crystallite size. J Appl Cryst 11: 102113.

30. Trivedi MK, Sethi KK, Panda P, Jana S (2017) A comprehensive physicochemical, thermal, and spectroscopic characterization of zinc (II) chloride using X-ray diffraction, particle size distribution, differential scanning calorimetry, thermo gravimetric analysis/differential thermogravimetric analysis, ultraviolet-visible, and Fourier transform-infrared spectroscopy. Int J Pharm Investig 7(1): 33-40.

31. Trivedi MK, Sethi KK, Panda P, Jana S (2017) Physicochemical, thermal and spectroscopic characterization of sodium selenate using XRD, PSD, DSC, TGA/DTG, UV-vis, and FT-IR. Marmara Pharmaceutical Journal 21(2): 311-318.

32. Inoue M, Hirasawa I (2013) The relationship between crystal morphology and XRD peak intensity on $\mathrm{CaSO}_{4} \cdot 2 \mathrm{H}_{2} \mathrm{O}$. J Crystal Growth 380: 169-175.

33. Raza K, Kumar P, Ratan S, Malik R, Arora S (2014) Polymorphism: The phenomenon affecting the performance of drugs. SOJ Pharm PharmSci 1(2): 10.

34. Brittain HG (2009) Polymorphism in pharmaceutical solids in Drugs and Pharmaceutical Sciences, 2 ${ }^{\text {nd }}$ (Edn.), Informa Healthcare USA.

35. Censi R, Martino PD (2015) Polymorph Impact on the Bioavailability and Stability of Poorly Soluble Drugs. Molecules 20(10): 18759-18776.

36. Blagden N, de Matas M, Gavan PT, York P (2007) Crystal engineering of active pharmaceutical ingredients to improve solubility and dissolution rates. Adv Drug Deliv Rev 59(7): 617-630.

37. Zhao Z, Xie M, Li Y, Chen A, Li G, et al. (2015) Formation of curcumin nanoparticles via solutionenhanced dispersion by supercritical $\mathrm{CO}_{2}$. Int $\mathrm{J}$ Nanomedicine 10: 3171-3181. 